\title{
Influence of Radiopacifier Additives on Calcium Aluminate Cement Properties
}

\author{
Ivone Regina de Oliveira $^{a *}$, Talita Luana de Andrade ${ }^{a}$, Daniele Coelho Matsuo ${ }^{a}$, \\ Renata Martins Parreira ${ }^{a}$, Marcos Jacobovitz ${ }^{b}$, Victor Carlos Pandolfelli ${ }^{c}$ \\ ${ }^{a}$ Institute for Research and Development, University of Vale do Paraíba - Univap, \\ Av. Shishima Hifumi, 2911, São José dos Campos, SP, Brazil \\ ${ }^{b}$ Private Practitioner in Endodontics, São Carlos, SP, Brazil \\ 'Materials Engineering Department, Federal University of São Carlos - UFSCar, \\ Rod. Washington Luiz, km 235, São Carlos, SP, Brazil
}

Received: March 16, 2014; Revised: July 8, 2014

\begin{abstract}
The aim of this study was to determine the best radiopaque additive to be incorporated to calcium aluminate cement (CAC) to promote radiopacity. Measurements of optical density were carried out on white MTA and CAC with and without additives such as: polymeric dispersant, plasticizer and various radiopacifiers. The effects of the radiopacifying addition on some properties of CAC were also evaluated. The radiopacity value for $\mathrm{CAC}-\mathrm{Bi}_{2} \mathrm{O}_{3}(25 \%)$ was higher than the other radiopacifying agents tested. The addition of $\mathrm{ZnO}(25 \%)$ and $15 \% \mathrm{ZnO}: 10 \% \mathrm{Bi}_{2} \mathrm{O}_{3}$ increased the compressive strength of $\mathrm{CAC}$, whereas for $\mathrm{Bi}_{2} \mathrm{O}_{3}(25 \%)$ containing samples the strength was lower than for the $\mathrm{CAC}$. The $\mathrm{ZnO}(25 \%)$ and $15 \% \mathrm{ZnO}: 10 \% \mathrm{Bi}_{2} \mathrm{O}_{3}$ additions also reduced the apparent porosity. CAC does not have sufficient radiopacity to be distinguished from adjacent anatomic structures, such as dental tissues and bone. The addition of $15 \% \mathrm{ZnO}: 10 \% \mathrm{Bi}_{2} \mathrm{O}_{3}$ can be suggested as the most suitable one to obtain the best compromise between good physical and mechanical properties and ideal radiopacity for clinical purposes.
\end{abstract}

Keywords: dental cement, radiopacity, physical and mechanical properties

\section{Introduction}

Mineral Trioxide Aggregate (MTA) has been considered as the ideal root-end filling material because of its low solubility, low cytotoxicity, good tissue tolerance and induction of mineralized tissue formation ${ }^{1}$. MTA is a white or grey powder which sets when there is moisture ${ }^{2,3}$. MTA primarily consists of tricalcium silicate $\left(3 \mathrm{CaO} . \mathrm{SiO}_{2}\right)$, dicalcium silicate $\left(2 \mathrm{CaO} . \mathrm{SiO}_{2}\right)^{4,5}$ as binder phases, and bismuth oxide to increase its radiopacity ${ }^{1}$.

Calcium aluminate cement (CAC) has been studied as root-end filling material to overcome some MTA drawbacks such as the long setting time and its negative implications for the clinical needs ${ }^{6-12}$. CAC has suitable physical and mechanical properties ${ }^{10}$, biocompatibility ${ }^{7,12}$, ability of stimulating hydroxyapatite deposition in simulated body fluid solution ${ }^{13}$ and acts as a barrier against bacterial microleakage ${ }^{8}$. Calcium aluminate-based cement showed no inflammatory and less tissue reactions than MTA, and it was biocompatible when tested in rat subcutaneous tissue ${ }^{6}$.

A key physical property for these endodontic materials is the radiopacity. Most endodontic materials contain radiopacifying agents to visualize the root canal filling and to check the healing evolution over time ${ }^{14}$. The rootend filling material should have enough radiopacity to be distinguished from adjacent anatomical structures, such as bones and teeth ${ }^{1,14,15}$.

*e-mail: ivoneregina.oliveira@gmail.com
The radiopacity of material is changed by adding particles containing heavy metals such as bismuth $(Z=83)$, barium $(Z=56)$, zirconium $(Z=40)$, strontium $(Z=38)$ or zinc $(Z=30)^{16,17}$.

Bismuth oxide is a well-known radiopacifying agent. However, previous studies pointed out that $\mathrm{Bi}_{2} \mathrm{O}_{3}$ affected the hydration mechanism of MTA, reducing the precipitation of calcium hydroxide in the hydrated paste ${ }^{18}$ and it was slightly leached out with the calcium hydroxide ${ }^{4}$.

The use of $\mathrm{Bi}_{2} \mathrm{O}_{3}$ with calcium silicate has been shown to be deleterious to the physical properties of the final material, affecting particularly the compressive strength ${ }^{19}$. The bismuth oxide is not inert and retards the hydration of the cement by decreasing its calcium ions release rate, changing its reparative capacity and its physicochemical properties $^{15}$.

Barium sulphate and zinc oxide are applied extensively in medical devices ${ }^{19}$. However, according to Vivan et al. ${ }^{14}$, $\mathrm{BaSO}_{4}$ itself does not provide suitable radiopacity to Portland cement. Zinc and zirconium oxides are used in dental materials for prosthetic and implant purposes and do not present toxicity ${ }^{15}$.

The extensive use of these materials indicates that they present favorable interaction with the tissues. However, adding them even at minimal amounts can affect the physical properties of the final compound. Besides its 
importance, there have been few investigations on the effect of radiopacifiers on the material's properties ${ }^{19}$.

Therefore, the aim of this study was to determine the best radiopaque additive to be incorporated to CAC to promote sufficient radiopacity for clinical purposes and the influence of this addition on some of its properties such as compressive strength, apparent porosity and setting time.

\section{Experimental Procedures}

White-MTA (Angelus, Londrina, PR-Brazil) and CAC (Secar 71, Kerneos, Neuilly sur Seine-France) were tested. The additives used are presented in Table 1.

The characteristics of the $\mathrm{ZnO}$ and $\mathrm{Bi}_{2} \mathrm{O}_{3}$ radiopacifiers, such as morphology and size distribution of particles, were analyzed by using the equipments scanning electron microscope (EVO MA10; Zeiss) and Sedigraph (5000D, Micromeritics) as showing in Figure 1. Further characterization of the materials was based on optical density, compressive strength, apparent porosity and setting time.

Aqueous suspensions of CAC ( $82 \mathrm{wt} \%$ solids) were prepared in the presence of a dispersant (D), plasticizer (P) and radiopacifying agents. Adding the dispersant and plasticizer reduced the water required to produce a workable mix of the calcium aluminate cement paste, resulting in a denser structure and, therefore, a stronger material ${ }^{10}$. Also, higher liquid to powder ratio was necessary to prepare the MTA suspension (75 wt $\%$ solids) used as control. The coagulated nature of the MTA particles does not result in fluid suspensions, unless they are diluted ${ }^{20}$.

The CAC or MTA suspensions were cast into circular metallic molds (10 $\mathrm{mm}$ diameter $\times 1 \mathrm{~mm}$ thick). Four specimens per each studied composition were prepared. The samples were cured for 24 hours at $37^{\circ} \mathrm{C}$ in a stove (MA033, Marconi) in a moisture-saturated environment ( $100 \% \mathrm{RH})$. After that, the samples unmolded were kept at $37^{\circ} \mathrm{C}$ for 24 more hours.

One sample of each composition was placed on an occlusal radiographic film (Kodak Insight, Manaus, Amazonas, Brazil) (Ref 1169143, Lot 39500204). At their side, a $99 \%$ pure aluminum step wedge with ten steps (1 to $10 \mathrm{~mm}$ ) was also placed on the radiographic film as shown in Figure 2. The radiographs were obtained using $70 \mathrm{KVp}$,
8 mA X-ray apparatus (ION 70X, Procion, Ribeirão Preto, São Paulo, Brazil) and exposed for 0.25 seconds at a focus-film distance of $20 \mathrm{~cm}$. The films were manually developed in a darkroom following the time/temperature recommendations of the manufacturer. The optical density value (OD) was measured with a photodensitometer (MRA; Indústria de Equipamentos Eletrônicos Ltda, Ribeirão Preto, São Paulo, Brazil). Optical density of the samples and each thickness of the aluminum step wedge were measured in triplicate for each film. The results of optical density represent the average of twelve measurements for each composition ( 3 measurements for each sample $\times 4$ samples for each composition). The optical density data of cements tested were submitted to a polynomial regression to obtain the equivalence in radiopacity $(\mathrm{mm} \mathrm{Al})^{15}$.

Aqueous suspensions of CAC ( $82 \mathrm{wt} \%$ solids) were also prepared in the presence of dispersant, plasticizer and the radiopacifying agents $\mathrm{ZnO}(25 \%), \mathrm{Bi}_{2} \mathrm{O}_{3}(25 \%)$ and $15 \% \mathrm{ZnO}: 10 \% \mathrm{Bi}_{2} \mathrm{O}_{3}$ and cast into $16 \mathrm{~mm}$ diameter $\times 18 \mathrm{~mm}$ height cylinder moulds for measurements of compressive strength and apparent porosity. Eight specimens per each studied composition were prepared (five for compressive strength and three for apparent porosity). Samples were cured at $37^{\circ} \mathrm{C}$ in a stove (MA033, Marconi, São Paulo, Brazil) in a moisture-saturated environment ( 100\% RH) for 12 hours. The samples were unmolded and placed into containers with simulated body fluid (SBF) solution at $37^{\circ} \mathrm{C}$ $(100 \% \mathrm{RH})$ for $3,7,15$ or 30 days.

The compressive strength of the samples was measured as a function of the exposition time in SBF, whereas others were dried at $110^{\circ} \mathrm{C}$ for $48 \mathrm{~h}$ and their apparent porosity was evaluated. The SBF solution was prepared according to the procedure described in the literature ${ }^{21}$.

The compressive strength was measured with the help of an EMIC Test Machine (Model DL 10.000, Curitiba, Brazil). A constant displacement rate of $0.15 \mathrm{~mm} / \mathrm{min}$ was used. The compressive strength was calculated as:

$\sigma_{R}=\left[\frac{4 P}{\pi D^{2}}\right]$

where, $\sigma_{\mathrm{R}}$ was the rupture stress $(\mathrm{MPa})$; $\mathrm{P}$ was the ultimate load $(\mathrm{N})$; and $\mathrm{D}(\mathrm{mm})$ was the diameter of the samples.

Table 1. Additives used as dispersant, plasticizer and radiopacifying agents.

\begin{tabular}{|c|c|c|c|}
\hline & Additives & $\begin{array}{c}\text { Content (wt \%) based on the } \\
\text { cement }\end{array}$ & Suspension composition \\
\hline Dispersant (D) & Polyglycol $^{1}$ & 0.6 & \multirow{2}{*}{ CAC-DP } \\
\hline \multirow[t]{5}{*}{ Plasticizer $(\mathrm{P})$} & $\mathrm{CaCl}_{2} \cdot 2 \mathrm{H}_{2} \mathrm{O}^{2}$ & 2.8 & \\
\hline & $\mathrm{BaSO}_{4}{ }^{3}$ & 25 & CAC-DP-BaSO \\
\hline & $\mathrm{Bi}_{2} \mathrm{O}_{3}{ }^{3}$ & 25 & CAC-DP- $\mathrm{Bi}_{2} \mathrm{O}_{3}$ \\
\hline & $\mathrm{ZrO}_{2}^{4}$ & 25 & CAC-DP- $\mathrm{ZrO}_{2}$ \\
\hline & $\mathrm{ZnO}^{2}$ & 25 & CAC-DP-ZnO (25\%) \\
\hline \multirow[t]{5}{*}{ Radiopacifiers } & $\mathrm{ZnO}^{2}$ & 30 & CAC-DP-ZnO (30\%) \\
\hline & $\mathrm{ZnO}^{2}$ & 35 & CAC-DP-ZnO (35\%) \\
\hline & $\mathrm{ZnO}: \mathrm{Bi}_{2} \mathrm{O}_{3}$ & $22.5 \% \mathrm{ZnO}: 2.5 \% \mathrm{Bi}_{2} \mathrm{O}_{3}$ & CAC-DP-22.5\% $\mathrm{ZnO}: 2.5 \% \mathrm{Bi}_{2} \mathrm{O}_{3}$ \\
\hline & $\mathrm{ZnO}: \mathrm{Bi}_{2} \mathrm{O}_{3}$ & $20 \% \mathrm{ZnO}: 5 \% \mathrm{Bi}_{2} \mathrm{O}_{3}$ & CAC-DP-20\% $\mathrm{ZnO}: 5 \% \mathrm{Bi}_{2} \mathrm{O}_{3}$ \\
\hline & $\mathrm{ZnO}: \mathrm{Bi}_{2} \mathrm{O}_{3}$ & $15 \% \mathrm{ZnO}: 10 \% \mathrm{Bi}_{2} \mathrm{O}_{3}$ & CAC-DP-15\%ZnO: $10 \% \mathrm{Bi}_{2} \mathrm{O}_{3}$ \\
\hline
\end{tabular}

${ }^{1}$ Bayer, Trostberg, Germany; ${ }^{2}$ Labsynth, Diadema, SP, Brazil; ${ }^{3}$ Vetec, Duque de Caxias, RJ, Brazil; ${ }^{4}$ Sigma-Aldrich, USA. 

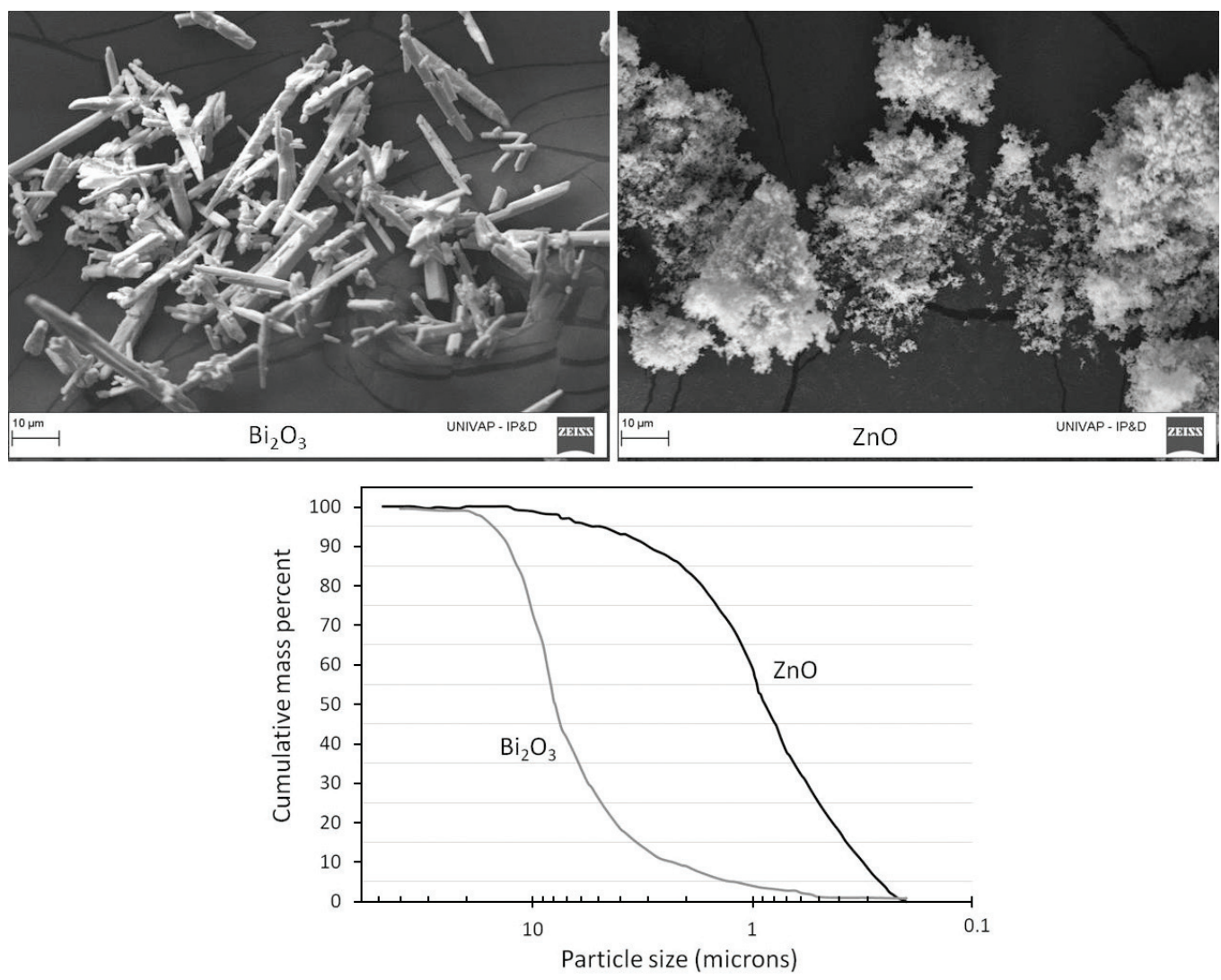

Figure 1. Characterization of radiopacifiers $\mathrm{ZnO}$ and $\mathrm{Bi}_{2} \mathrm{O}_{3}$ as morphology and size distribution of particles.

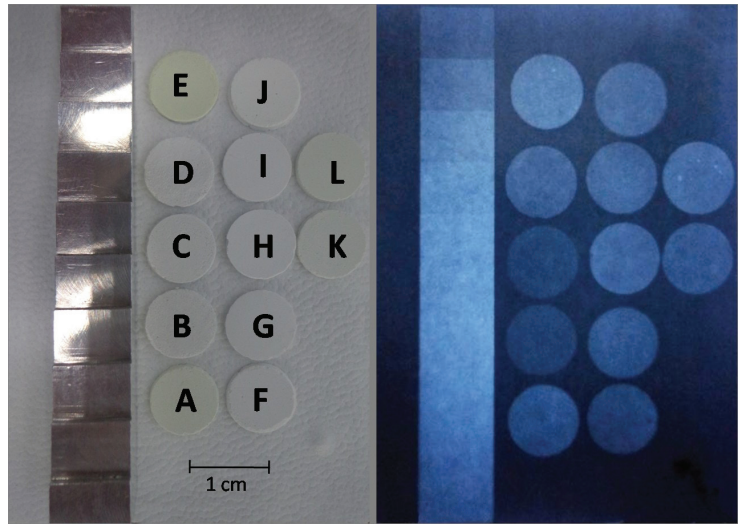

Figure 2. Example of the radiographic procedure. A) white-MTA (WMTA), B) CAC, C) CAC-DP, D) CAC-DP-BaSO 4 (25\%), E) CAC-DP-Bi ${ }_{2} \mathrm{O}_{3}(25 \%)$, F) CAC-DP- $\mathrm{ZrO}_{2}(25 \%)$, G) CAC-DP-ZnO (25\%), H) CAC-DP-ZnO (30\%), I) CAC-DP-ZnO (35\%), J) CACDP-22.5\% $\mathrm{ZnO}: 2.5 \% \mathrm{Bi}_{2} \mathrm{O}_{3} \mathrm{~K}$ ) CAC-DP-20\% $\mathrm{ZnO}: 5 \% \mathrm{Bi}_{2} \mathrm{O}_{3}$ and $\mathrm{L}$ ) CAC-DP-15\% $\mathrm{ZnO}: 10 \% \mathrm{Bi}_{2} \mathrm{O}_{3}$ (D and $\mathrm{P}$, indicates dispersant and plasticizer, respectively).

The apparent porosity was evaluated according to the immersion test (Archimedes principle), using kerosene. This principle states that a body immersed in a fluid is buoyed up by a force equal to the weight of the displaced fluid. The buoyant force is measured by the difference, expressed in grams, between the weight of the body in air and when submerged in kerosene ${ }^{22}$.
The samples are initially weighed in dry conditions $\left(\mathrm{W}_{\mathrm{d}}\right)$. After 1 hour of immersion in the liquid under vacuum, the sample is weighed both suspended in the immersion liquid $\left(\mathrm{W}_{\mathrm{i}}\right)$ and humid $\left(\mathrm{W}_{\mathrm{h}}\right)$. Thereby, the apparent porosity (A.P) of the sample is calculated considering the mass of liquid retained in its open pores:

$$
\text { A.P. }=\left(\frac{\left(\mathrm{W}_{\mathrm{h}}-\mathrm{W}_{\mathrm{d}}\right)}{\left(\mathrm{W}_{\mathrm{h}}-\mathrm{W}_{\mathrm{i}}\right)}\right) \times 100
$$

Aqueous suspensions of CAC (82 wt\% solids) were also prepared using a standard laboratory mixer (Marconi, Piracicaba, Brazil) under $2000 \mathrm{rpm}$. The setting time of CAC suspensions was evaluated in the presence of dispersant, plasticizer and radiopacifying agents $\mathrm{ZnO}(25 \%), \mathrm{Bi}_{2} \mathrm{O}_{3}$ (25\%) and $15 \% \mathrm{ZnO}: 10 \% \mathrm{Bi}_{2} \mathrm{O}_{3}$. After mixing for $1 \mathrm{~min}$, the suspensions were poured into a container $(180 \mathrm{~mL})$ where the setting time was measured with an automatic recording Vicat apparatus (Vicatronic E044, Matest, Italy). A needle is inserted in the suspension every $1 \mathrm{~min}$. The time for which the penetration distance was zero indicated the setting time of the sample.

\section{Results and Discussion}

\subsection{Radiopacity tests}

The optical density of the aluminum step wedge measured for different radiographs is shown in Figure 3. 
The constancy of the optical density on the 4 radiographs showed the precision of the measurement. As expected, a decrease in OD was observed with increasing the step wedge thickness, as the image progressively became more radiopaque ${ }^{15}$.

The radiopacity for each tested material is expressed in millimeters of equivalent aluminum as shown in Figure 4. The radiopacity value for CAC-DP- $\mathrm{Bi}_{2} \mathrm{O}_{3}(25 \%)$ was higher than the other radiopacifying agents tested, including the commercial material (WMTA) which includes bismuth oxide in its composition. The CAC-DP- $15 \% \mathrm{ZnO}: 10 \% \mathrm{Bi}_{2} \mathrm{O}_{3}$ composition presented sufficient radiopacity for clinical purposes, similarly to MTA.

$\mathrm{Bi}_{2} \mathrm{O}_{3}$ is used as a radiopacifying agent for dental material such as acrylic resin and some MTAs imparting the sufficient radiopacity to them ${ }^{15,19}$. Among all additives evaluated, $\mathrm{Bi}_{2} \mathrm{O}_{3}$ addition resulted the lowest optical density (OD).

ISO $6876: 2012^{23}$ standard establishes $3 \mathrm{~mm} \mathrm{Al}$ as the minimum radiopacity for the root canal sealers. When the

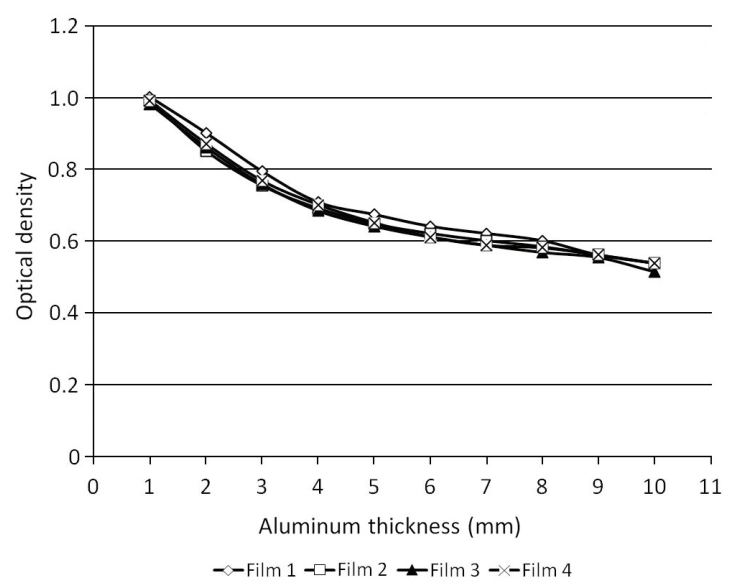

Figure 3. Optical density of the aluminum step wedge measured for four radiographs.
OD values obtained for each material were converted into radiopacity, results higher than $3 \mathrm{~mm} \mathrm{Al}$ were obtained mainly for CAC-DP- $\mathrm{Bi}_{2} \mathrm{O}_{3}(25 \%)$. This composition presented higher radiopacity than all other radiopacifying agents tested. CAC-DP-ZnO (25\%) resulted in a lower value than that required $(2.2 \mathrm{~mm} \mathrm{Al}$, Figure 4$)$ to allow radiographic differentiation among the cement and dental structures. Based on that, higher contents of $\mathrm{ZnO}$ were evaluated and also the mixture with $\mathrm{Bi}_{2} \mathrm{O}_{3}$ in different proportions. CAC-DP-15\% $\mathrm{ZnO}: 10 \% \mathrm{Bi}_{2} \mathrm{O}_{3}$ compositions presented suitable radiopacity $(3.5 \mathrm{~mm} \mathrm{Al})$, similarly to MTA.

Aguilar et al. ${ }^{15}$ also pointed out that $\mathrm{Bi}_{2} \mathrm{O}_{3}$ was efficient radiopacifier for cement based calcium aluminate cement, providing suitable results for all studied thicknesses. However, the present authors highlight that further research was required to evaluate the effect of the addition of this radiopacifying agent on other physicomechanical and biological properties of cement because it has been reported that bismuth is toxic and induces cell death ${ }^{24}$. Other authors also affirmed that the effect that particle shape and particle size distribution of a cement-replacing material have on the properties of the resultant material still needs to be investigated $^{19}$.

Therefore, the influence of $\mathrm{ZnO}(25 \%), \mathrm{Bi}_{2} \mathrm{O}_{3}(25 \%)$ or their mixture $\left(15 \% \mathrm{ZnO}: 10 \% \mathrm{Bi}_{2} \mathrm{O}_{3}\right)$ on some properties of CAC such as compressive strength, apparent porosity and setting time, was evaluated.

\subsection{Compressive strength and apparent porosity tests}

Results of compressive strength and apparent porosity as a function of the curing time, for samples of calcium aluminate cement containing additives (dispersant, plasticizer, and radiopacifier) are shown in Figures $5 \mathrm{a}$ and $\mathrm{b}$, respectively.

The addition of $\mathrm{ZnO}(25 \%)$ and $15 \% \mathrm{ZnO}: 10 \% \mathrm{Bi}_{2} \mathrm{O}_{3}$ increased the compressive strength of CAC-DP, whereas to $\mathrm{Bi}_{2} \mathrm{O}_{3}(25 \%)$ the values were lower than the CAC-DP. The

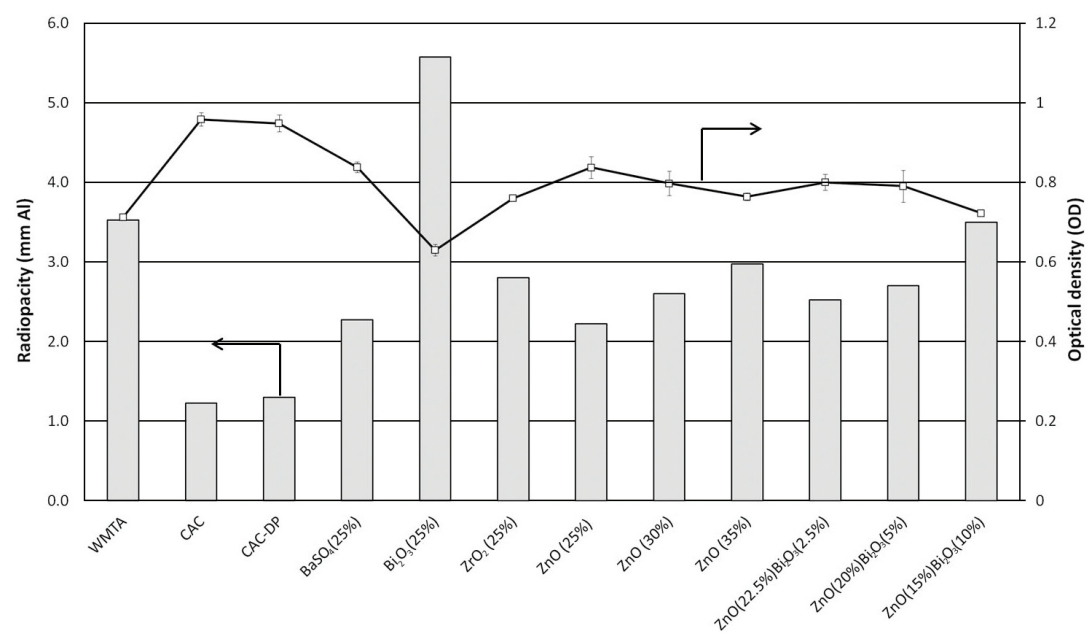

Figure 4. Mean radiopacity values expressed as aluminum thickness ( $\mathrm{mm} \mathrm{Al}$ ) and the optical density for the tested materials: white-MTA, main calcium aluminate cement (CAC) or containing additives dispersant (D), plasticizer (P) and radiopacifiers. 

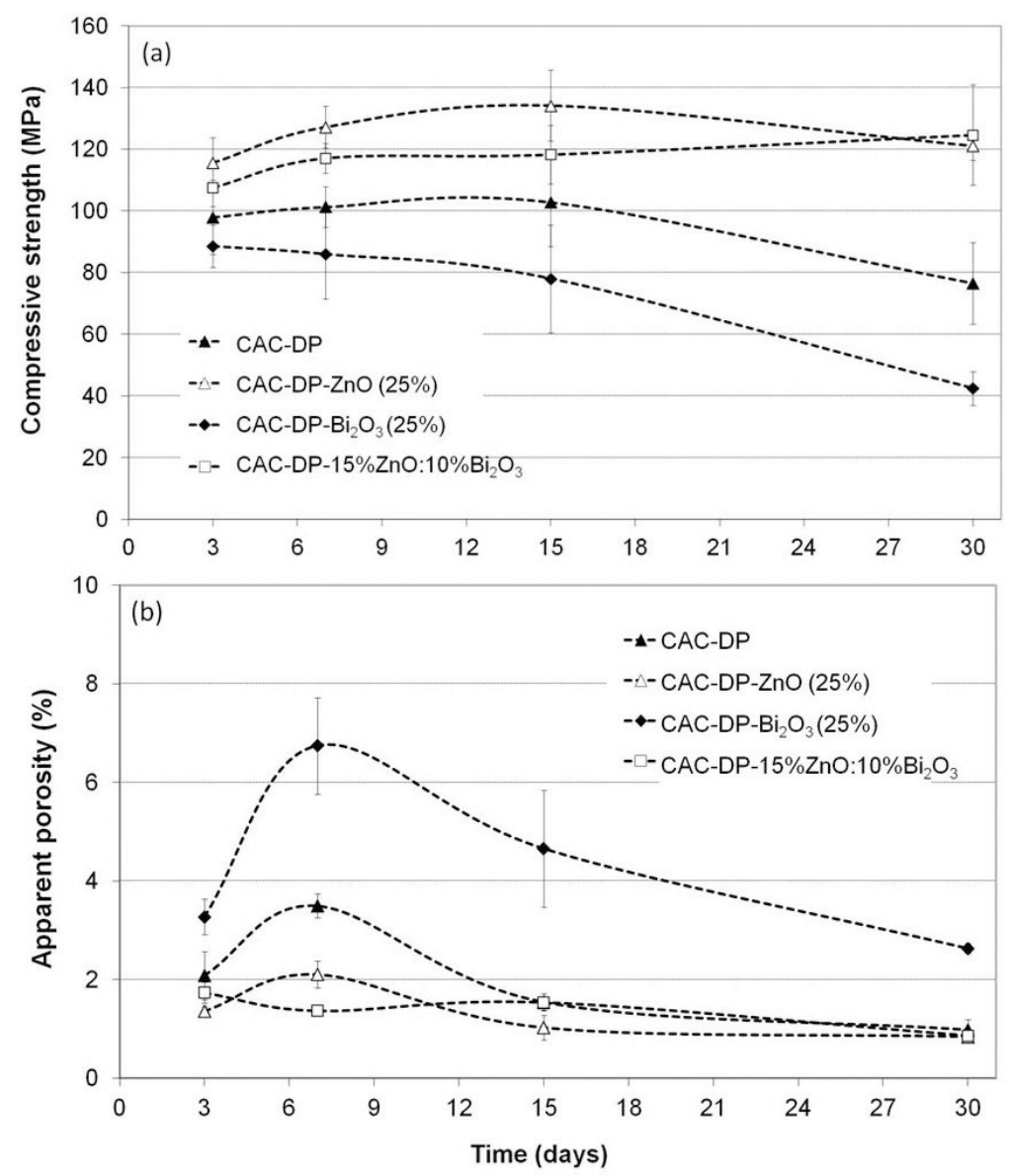

Figure 5. (a) Compressive strength and (b) apparent porosity as a function of the curing time for samples of calcium aluminate cement $(\mathrm{CAC})$ containing additives dispersant $(\mathrm{D})$, plasticizer $(\mathrm{P})$ and radiopacifiers. Error bars represent variation of measurements among the samples (five of them for compressive strength and three for apparent porosity).

$\mathrm{ZnO}(25 \%)$ and $15 \% \mathrm{ZnO}: 10 \% \mathrm{Bi}_{2} \mathrm{O}_{3}$ addition also decreased the apparent porosity compared to the $\mathrm{Bi}_{2} \mathrm{O}_{3}(25 \%)$ ones.

An important feature that must be considered when choosing a radiopacifier additive is the mechanical strength of the resulting material. Compressive strength is an important factor to consider when the filling material is placed in a cavity that bears occlusal pressure, such as a root canal filling ${ }^{3}$, or even a restorative base. The addition of $\mathrm{ZnO}(25 \%)$ increased the mechanical strength of CAC-DP when compared to $\mathrm{Bi}_{2} \mathrm{O}_{3}(25 \%)$ as shown in Figure 5a. $\mathrm{ZnO}$ comprises finer particles than $\mathrm{Bi}_{2} \mathrm{O}_{3}$ (Figure 1) positively affecting the particle packing, resulting in lower porosity (Figure 5b) and consequently higher mechanical strength. On the other hand, $\mathrm{Bi}_{2} \mathrm{O}_{3}$ increases the porosity and decreases the mechanical strength of calcium aluminate cement as their particles that have wide size range and elongated shape. The addition of $15 \% \mathrm{ZnO}: 10 \% \mathrm{Bi}_{2} \mathrm{O}_{3}$ mixture to $\mathrm{CAC}$ resulted in close values of compressive strength compared to $\mathrm{ZnO}(25 \%)$ and also lower apparent porosity than the $\mathrm{Bi}_{2} \mathrm{O}_{3}(25 \%)$ one. Both $\mathrm{ZnO}(25 \%)$ and $15 \% \mathrm{ZnO}: 10 \% \mathrm{Bi}_{2} \mathrm{O}_{3}$ mixture additions also resulted in a lower decrease of the mechanical strength over time.

Camilleri and Galdolfi ${ }^{19}$ also showed that $\mathrm{ZnO}$ (Fischer Scientific) presents very fine particles (lower $3 \mu \mathrm{m}$ ) which are difficult to be distinguished by SEM even at high magnification. On the other hand, $\mathrm{Bi}_{2} \mathrm{O}_{3}$ (Fischer Scientific) shows elongated needle like shape particles and showed a wide particle size range $(5-100 \mu \mathrm{m})$.

The calcium aluminate cement dissolution in contact with water promotes the release of $\mathrm{Ca}^{2+}$ and $\mathrm{Al}(\mathrm{OH})_{4}^{-}$ions, which is followed by precipitation of calcium aluminate hydrate $(\mathrm{CAH})$ and aluminium hydroxide $(\mathrm{AH})$ due to the saturation of the solution ${ }^{25}$. The type of hydrate formed determines the material properties such as mechanical strength and porosity. The time favors conversion of less stable hydrates $\left(\mathrm{CAH}_{10}\right.$, less dense) to a more stable one $\left(\mathrm{C}_{3} \mathrm{AH}_{6}\right.$, more dense) which may explain the decrease in mechanical strength. The precipitation of $\mathrm{AH}_{3}$ gel occurs simultaneously inducing the decrease in apparent porosity with time.

\subsection{Setting time tests}

Measurements of setting time using Vicat apparatus were taken for CAC suspensions with dispersant, plasticizer and the following radiopacifying agents $\mathrm{ZnO}(25 \%), \mathrm{Bi}_{2} \mathrm{O}_{3}$ $(25 \%)$ and $15 \% \mathrm{ZnO}: 10 \% \mathrm{Bi}_{2} \mathrm{O}_{3}$, as shown in Figure 6. $\mathrm{ZnO}$ slightly retarded setting, whereas $\mathrm{Bi}_{2} \mathrm{O}_{3}$ accelerated setting. 


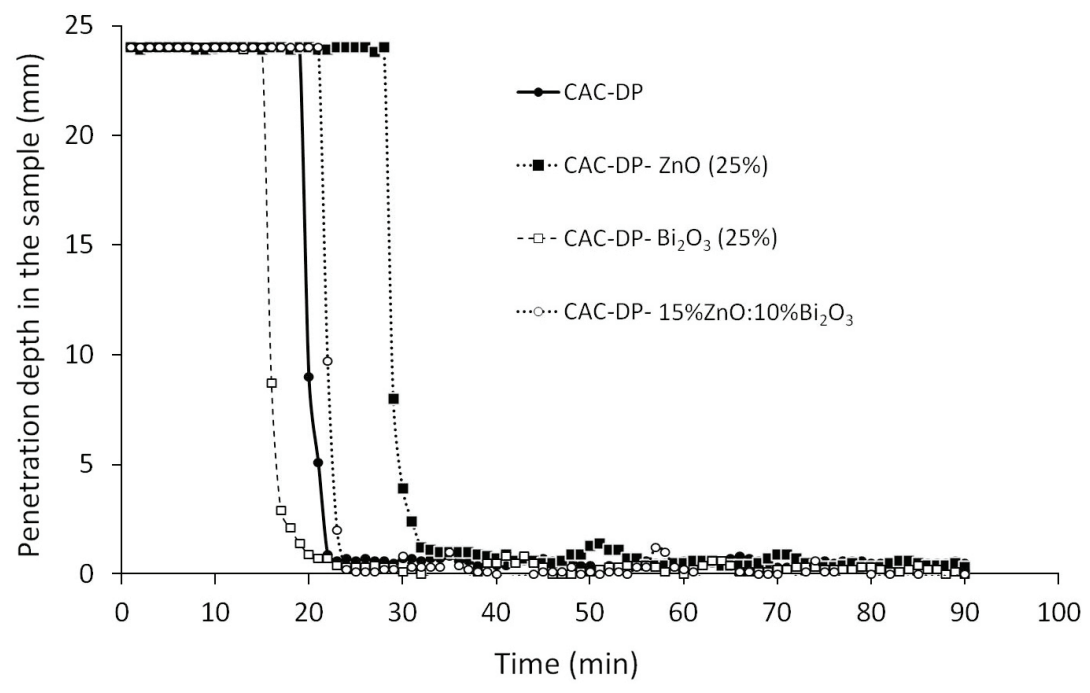

Figure 6. Evaluation of setting time of aqueous suspensions of calcium aluminate cement (CAC, $82 \mathrm{wt} \%$ solids) containing additives dispersant (D), plasticizer $(\mathrm{P})$ and radiopacifiers.

Another important feature for application of CAC as dental material is the setting time. CAC-DP showed a reduced value (close to $20 \mathrm{~min}$.), which matched to the clinical requirements. Additionally, the additives showed little influence on the setting time of CAC-DP compositions [ $25 \mathrm{wt} \%$ of $\mathrm{ZnO}$ (close to $29 \mathrm{~min}$.), $25 \mathrm{wt} \%$ of $\mathrm{Bi}_{2} \mathrm{O}_{3}$ (close to $16 \mathrm{~min}$.) and $15 \% \mathrm{ZnO}: 10 \% \mathrm{Bi}_{2} \mathrm{O}_{3}$ (close to $23 \mathrm{~min}$ )]. The advantage of using cement with a reduced setting time is the less likelihood of constant professional procedures during the treatment. When used as a root-end or root-canal filling material the faster hardening should also reduce the risk of contamination and dislodgement after placement $\mathrm{t}^{20,26}$.

It is noteworthy that similar tests of compressive strength, apparent porosity and setting time using CAC-DP when compared with MTA were previously shown by the authors ${ }^{10}$. The CAC presented better fluidity, improved handling properties, greater mechanical strength, and reduced porosity with lower pore size when compared with MTA Angelus.

\section{Conclusions}

The effect of different additives not only on radiopacity but also on some physical and mechanical properties of

\section{References}

1. Tanomaru-Filho M, Silva GF, Duarte MAH, Gonçalves M and Tanomaru JMG. Radiopacity evaluation of root-end filling materials by digitalization of images. Journal of Applied Oral Science. 2008; 16(6):376-379. PMid:19082394. http://dx.doi. org/10.1590/S1678-77572008000600004

2. Santos AD, Moraes JC, Aráujo EB, Yukimitu K and Valério Filho WV. Physico-chemical properties of MTA and a novel experimental cement. International Endodontic Journal. 2005; 38(7):443-447. PMid:15946264. http://dx.doi.org/10.1111/ j.1365-2591.2005.00963.x calcium aluminate cement used in endodontic treatments was compared. The radiopacifier compound that leads to a higher benefit is $\mathrm{Bi}_{2} \mathrm{O}_{3}$ but it increases the porosity and decreases the mechanical strength of calcium aluminate cement due to their wide particle size range and elongated shape. On the other hand, the $\mathrm{ZnO}$ is comprised by much finer particles than $\mathrm{Bi}_{2} \mathrm{O}_{3}$ which positively affected the particle packing resulting in the increase of mechanical strength of CAC. Nevertheless, $\mathrm{ZnO}$ results in a lower value of radiopacity than that required by ISO 6876:2012. This work shows that it is possible to attain suitable radiopacity for clinical purposes using lower additive content besides the better compromise between physical and mechanical properties by using the mixture $\mathrm{ZnO}$ with $\mathrm{Bi}_{2} \mathrm{O}_{3}$, specially $15 \% \mathrm{ZnO}: 10 \% \mathrm{Bi}_{2} \mathrm{O}_{3}$.

\section{Acknowledgments}

The authors are grateful to grant \#2009/17451-0, São Paulo Research Foundation and National Council for Scientific and Technological Development - Brazil for providing financial support for this research.

3. Torabinejad M, Hong CU, McDonald F and Pitt Ford TR. Physical and chemical properties of a new root-end filling material. Journal of Endodontics. 1995; 21(7):349-353. http:// dx.doi.org/10.1016/S0099-2399(06)80967-2

4. Camilleri J. Characterization of hydration products of mineral trioxide aggregate. International Endodontic Journal. 2008; 41(5):408-417. PMid:18298574. http://dx.doi.org/10.1111/ j.1365-2591.2007.01370.x

5. Dammaschke T, Gerth HU, Zuchner H and Schäfer E. Chemical and physical surface and bulk material characterization of white ProRoot MTA and two Portland cements. Dental 
Materials. 2005; 21(8):731-738. PMid:15935463. http://dx.doi. org/10.1016/j.dental.2005.01.019

6. Aguilar FG, Roberti GLF and Panzeri Pires-de-Souza FC. Biocompatibility of new calcium aluminate cement (EndoBinder). Journal of Endodontics. 2012; 38(3):367-371. PMid:22341076. http://dx.doi.org/10.1016/j.joen.2011.11.002

7. Castro-Raucci LM, Oliveira IR, Teixeira LN, Rosa AL, Oliveira PT and Jacobovitz M. Effects of a novel calcium aluminate cement on the early events of the progression of osteogenic cell cultures. Brazilian Dental Journal. 2011; 22(2):99-104. Available from: <http://www.ncbi.nlm.nih. gov/pubmed/21537581>. PMid:21537581. http://dx.doi. org/10.1590/S0103-64402011000200002

8. Jacobovitz M, Vianna ME, Pandolfelli VC, Oliveira IR, Rossetto HL and Gomes BPFA. Root canal filling with cements based on mineral aggregates: An "in vitro" analysis of bacterial microleakage. Oral Surgery Oral Medicine Oral Pathology Oral Radiology and Endodontics. 2009; 108(1):140-144. PMid:19540451. http://dx.doi.org/10.1016/j. tripleo.2009.03.013

9. Loof J, Engqvist H, Ahnfelt NO, Lindqvist $\mathrm{K}$ and Hermansson L. Mechanical properties of a permanent dental restorative material based on calcium aluminate. Journal of Materials Science Materials in Medicine. 2003; 14(12):1033-1037. PMid:15348495. http://dx.doi.org/10.1023/ B:JMSM.0000003999.52349.0d

10. Oliveira IR, Pandolfelli VC and Jacobovitz M. Chemical, physical and mechanical properties of a novel calcium aluminate endodontic cement. International Endodontic Journal. 2010; 43(12):1069-1076. PMid:20726916. http:// dx.doi.org/10.1111/j.1365-2591.2010.01770.x

11. Pandolfelli VC, Oliveira IR, Rossetto HL and Jacobovitz M. Aluminous cement-based composition for application in endodontics and cementitious product obtained thereof. Patent WO 2009067774 A2. 2009 Jun 4.

12. Silva EJ, Herrera DR, Almeida JF, Ferraz CC, Gomes BP and Zaia AA. Evaluation of cytotoxicity and up-regulation of gelatinases in fibroblast cells by three root repair materials. International Endodontic Journal. 2012; 45(9):815820. PMid:22452531. http://dx.doi.org/10.1111/j.13652591.2012.02038.x

13. Oliveira IR, Andrade TL, Jacobovitz M and Pandolfelli VC. Bioactivity of calcium aluminate endodontic cement. Journal of Endodontics. 2013; 39(6):774-778. PMid:23683278. http:// dx.doi.org/10.1016/j.joen.2013.01.013

14. Vivan RR, Ordinola-Zapata R, Bramante CM, Bernardineli N, Garcia RB and Hungaro Duarte MAH et al. Evaluation of the radiopacity of some commercial and experimental root-end filling materials. Oral Surgery Oral Medicine Oral Pathology Oral Radiology and Endodontics. 2009; 108(6):e35-e38. PMid:19913718. http://dx.doi.org/10.1016/j. tripleo.2009.07.037
15. Aguilar FG, Garcia LFR, Rossetto HL, Pardini LC and Panzeri Pires-de-Souza FC. Radiopacity evaluation of calcium aluminate cement containing different radiopacifying agents. Journal of Endodontics. 2011; 37(1):67-71. PMid:21146080. http://dx.doi.org/10.1016/j.joen.2010.10.001

16. Cruvinel DR, Garcia LFR, Casemiro LA, Pardini LC, and Panzeri Pires-de-Souza FC. Evaluation of radiopacity and microhardness of composites submitted to artificial aging. Materials Research. 2007; 10(3):325-329. http://dx.doi. org/10.1590/S1516-14392007000300021

17. Tirapelli C, Panzeri FC, Panzeri H, Pardini LC and Zaniquelli O. Radiopacity and microhardness changes and effect of X-ray operating voltage in resin-based materials before and after the expiration date. Materials Research. 2004; 7(3):409-412. http:// dx.doi.org/10.1590/S1516-14392004000300006

18. Camilleri J. Hydration mechanisms of mineral trioxide aggregate. International Endodontic Journal. 2007; 40(6):462470. PMid:17459120. http://dx.doi.org/10.1111/j.13652591.2007.01248.x

19. Camilleri J and Gandolfi MG. Evaluation of the radiopacity of calcium silicate cements containing different radiopacifiers. International Endodontic Journal. 2010; 43(1):21-30. PMid:19891720. http://dx.doi.org/10.1111/j.13652591.2009.01621.x

20. Camilleri J. Modification of mineral trioxide aggregate. Physical and mechanical properties. International Endodontic Journal. 2008; 41(10):843-849. PMid:18699790. http://dx.doi. org/10.1111/j.1365-2591.2008.01435.x

21. Rigo ECS, Boschi AO, Yoshimoto M, Allegrini S, Konig B and Carbonari MJ. Evaluation in vitro and in vivo of biomimetic hydroxyapatite coated on titanium dental implants. Materials Science and Engineering: C. 2004; 24(5):647-651. http:// dx.doi.org/10.1016/j.msec.2004.08.044

22. Fridland M and Rosado R. Mineral trioxide aggregate (MTA) solubility and porosity with different water-to-powder ratios. Journal of Endodontics. 2003; 29(12):814-817. PMid:14686812. http://dx.doi.org/10.1097/00004770200312000-00007

23. International Organization for Standardization - ISO. ISO 6876:2012: dentistry: root canal sealing materials. Genève; 2001.

24. Camilleri J, Montesin FE, Papaioannou S, McDonald F and Pitt Ford TR. Biocompatibility of two commercial forms of mineral trioxide aggregate. International Endodontic Journal. 2004; 37(10):699-704. PMid:15347295. http://dx.doi. org/10.1111/j.1365-2591.2004.00859.x

25. Parker KM and Sharp JH. Refractory calcium aluminate cements. Journal of the British Ceramic Society. 1982; 81:35-42.

26. Camilleri J. The physical properties of accelerated Portland cement for endodontics use. International Endodontic Journal. 2008; 41:151-157. PMid:17931386. 